\title{
INFLUENCE OF NITROGEN APPLICATION RATE AND METEOROLOGICAL CONDITIONS ON $\beta$-GLUCAN CONTENT IN NAKED AND HUSKED OAT GRAIN
}

\author{
Linda Brunava\#, Laila Vilmane, and Sanita Zute \\ State Stende Cereal Breeding Institute, Dižstende, "Dižzemes", Lībagi Civil Parish, Talsi County, LV-3258, LATVIA \\ linda.brunava@gmail.com \\ \# Corresponding author
}

Communicated by Dalija Segliṇa

The objective of this study was to determine the effect of applied nitrogen fertilizer rate on $\beta$-glucan content in oat (Avena sativa L.) grains. The study was carried out at the State Stende Cereal Breeding Institute from 2011 to 2014. Three nitrogen surface fertiliser treatments (80, 120 and $160 \mathrm{~kg} \cdot \mathrm{ha}^{-1}$ ) were applied on one husked oat (variety 'Lizete') and two naked oat genotypes (breeding lines 'S-156' and '33793'). The content of $\beta$-glucan in naked oat genotypes was significantly $(p<0.05)$ higher than in the husked genotype. The difference in $\beta$-glucan content between the naked breeding lines was not significant $(p>0.05)$. Significant $(p<0.05)$ differences in $\beta$-glucan content were observed between nitrogen treatments only for husked oat genotype 'Lizete'. Effect of growing season on $\beta$-glucan content was significant $(p<0.05)$ for both (naked and husked) oat genotypes. $\beta$-glucan content of naked oat breeding lines ('S-156' and '33793') was significantly $(p<0.05)$ higher in 2011 comparing with 2012 and 2013, due to differences in precipitation during the grain filling period.

Key words: Avena sativa, genotype and environment interaction, hydrothermal coefficient, nitrogen, $\beta$-glucans.

\section{INTRODUCTION}

Oat (Avena sativa L.) is small grain cereal crop. It has the fourth largest area harvested in Europe, after wheat (Triticum spp.), barley (Hordeum vulgare L.), and maize (Zea mays L.) (Anonymous, 2014). Oat grain is characterised by good taste, dietetic properties, and activity that stimulates metabolic changes. It is part of a healthy diet for humans and is used in animal nutrition. Oat can be classified into husked and naked oat. For both kernels are in husks, but naked oat husk easily separates during harvesting, while husked oat husk must be mechanically removed before using in human nutrition. Naked oat usually has better quality parameters compared with husked oat cultivars (Biel et al., 2009). Husked oat with removed husk has equal or a slightly higher quality in several parameters, for example, protein content, several fatty acids and beta-glucan content (Biel et al., 2014).

Beta-glucan ( $\beta$-glucan) is an important component of water-soluble dietary fibre, which is found only in plants. $\beta$-glucan has unique functional and nutritional properties. It is found in grain endosperm and germ, but germ $\beta$-glucan has higher dietetic value. It is known that oat $\beta$-glucan controls blood glucose and cardiovascular diseases and has beneficial impact on diabetic patients (Wood, 2007; Sadiq Butt et al., 2008). $\beta$-glucan content in oat grains is between 17.3 to $57.0 \mathrm{~g} \cdot \mathrm{kg}^{-1}$ (Havrlentova and Kraic, 2006), depending on genotype and agroecological factors. There are several studies on effect of environmental conditions and fertiliser rates on $\beta$-glucan content (Saastamoinen et al., 2004; Tiwari and Cummins, 2009; Havrlentova et al., 2013). Climatic factors can limit oat growth and development. Temperature and precipitation are the most important climatic factors affecting $\beta$-glucan content. $\beta$-glucan accumulates late in grain development, and stress created by temperature and precipitation factors can cause early end of grain development and reduced $\beta$-glucan concentration in grains (Tiwari and Cummins, 2009). Nitrogen fertilizers are usually used to increase yield. Higher nitrogen application rates increase protein and $\beta$-glucan concentration in grains (Fan et al., 2009).

The aim of this study was to determine the effects of applied nitrogen fertilizer rates and meteorological conditions on $\beta$-glucan content in oat grains.

\section{MATERIALS AND METHODS}

The field experiments were carried out at the State Stende Cereal Breeding Institute (57 $11^{\circ} 34.526^{\prime \prime} \mathrm{N} 22^{\circ} 33^{\prime} 19.3^{\prime \prime} \mathrm{E}$, $78 \mathrm{~m}$ above mean sea level) from 2011 to 2014 . Three oat genotypes with known relatively high quality of $\beta$-glucans, 
Table 1

AGRONOMIC PROTOCOLS APPLIED IN FIELD EXPERIMENTS (2011-2014, STATE STENDE CEREAL BREEDING INSTITUTE)

\begin{tabular}{|c|c|c|c|c|}
\hline Year & $\begin{array}{c}\text { Sowing } \\
\text { date }\end{array}$ & $\begin{array}{c}\text { Harvesting } \\
\text { date }\end{array}$ & Soil composition & Pre-crop \\
\hline 2011 & April 23 & August 19 & $\begin{array}{l}\text { Humus content } 21 \mathrm{~g} \mathrm{~kg}^{-1} \\
\mathrm{pH} \mathrm{KCl} 5.4, \mathrm{P}^{2} 8 \mathrm{mg} \mathrm{kg}^{-1} \\
\mathrm{~K} 78 \mathrm{mg} \mathrm{kg}^{-1}\end{array}$ & Spring wheat \\
\hline 2012 & April 28 & August 9 & $\begin{array}{l}\text { Humus content } 18 \mathrm{~g} \mathrm{~kg}^{-1} \text {, } \\
\mathrm{pH} \mathrm{KCl} 6.2, \mathrm{P}^{2} 4 \mathrm{mg} \mathrm{kg}^{-1} \text {, } \\
\text { K } 59 \mathrm{mg} \mathrm{kg}^{-1}\end{array}$ & Spring barley \\
\hline 2013 & May 3 & August 7 & $\begin{array}{l}\text { Humus content } 20 \mathrm{~g} \mathrm{~kg}^{-1} \text {, } \\
\mathrm{pH} \mathrm{KCl} 6.6, \mathrm{P} 39 \mathrm{mg} \mathrm{kg}^{-1} \text {, } \\
\text { K } 53 \mathrm{mg} \mathrm{kg}^{-1}\end{array}$ & Spring barley \\
\hline 2014 & April 22 & August 22 & $\begin{array}{l}\text { Humus content } 22 \mathrm{~g} \mathrm{~kg}^{-1} \\
\mathrm{pH} \mathrm{KCl} 6.0, \mathrm{P} 99 \mathrm{mg} \mathrm{kg}^{-1} \\
\mathrm{~K} 150 \mathrm{mg} \mathrm{kg}^{-1}\end{array}$ & Potatoes \\
\hline
\end{tabular}

lipid and amino acid composition were studied: one husked oat variety - 'Lizete' (Stende/Latvia), and two perspective breeding lines of naked oats — 'S-156' (Stende) and '33793' (Stende). Three nitrogen application treatments (80, 120 and $160 \mathrm{~kg} \cdot \mathrm{ha}^{-1}$ ) were used after sowing. Agronomic protocols applied in field experiments are presented in Table 1. All agro-technical operations were carried out at optimal terms according to weather conditions during the vegetation period and depending on plant development stages. Complex mineral fertilizer NPK was used as a basic fertilizer at rate $500 \mathrm{~kg} \cdot \mathrm{ha}^{-1}$ (pure matter $\mathrm{N}-51 \mathrm{~kg} \cdot \mathrm{ha}^{-1}, \mathrm{P}-30 \mathrm{~kg} \cdot \mathrm{ha}^{-1}$, $\mathrm{K}-42 \mathrm{~kg} \cdot \mathrm{ha}^{-1}$ ) each year. Concentration of potassium in soil was lower in 2012 and 2013 than in 2011 and 2014. Seeding rate was 500 germinating seeds $1 \mathrm{~m}^{-2}$. Variants were arranged in four replications with plot size $12 \mathrm{~m}^{2}$ in a randomized block design.

To compare stability of $\beta$-glucan content in oat grains due to climatic factors under different nitrogen application rates during four years, meteorological parameters like the Seljaninov hydrothermal coefficient (HTC) (Taparauskiene et al., 2013), mean daily temperature and sum of precipitation were calculated. HTC was calculated separately for three periods associated with nitrogen application effectivity (HTC I - period from sowing to nitrogen application, HTC II - first week after nitrogen application, HTC III — second week after nitrogen application) and sepa- rately for each month. HTC is calculated from $\mathrm{P}$, daily precipitation sum; and $\mathrm{T}$, mean daily temperature, using only values higher than $10{ }^{\circ} \mathrm{C}$ :

$$
H T C=\frac{10 \sum_{i=1}^{n} P_{i}}{\sum_{i=1}^{n} T_{i}}
$$

HTC values indicate the integrated effect of precipitation and mean daily temperature (HTC 0.5 - extremely dry, HTC $0.5-0.7$ - very dry, HTC $0.7-0.9$ - dry, HTC 1.0-1.3 - insufficiently wet, HTC 1.3-1.5 - moderately wet, HTC 1.5-2.0 — wet, HTC 2.0-3.0 — very wet, and HTC 3.0 - extremely wet) (Taparauskiene et al., 2013). Mean daily temperatures and sum of precipitation dynamics during the vegetation period are given in Figure 1. Meteorological conditions in April and May were sufficient for oat growing. The sum of atmospheric precipitation and mean daily temperature in July and August were higher in 2011 than the long-term average, and dryer conditions were observed in 2013, when atmospheric precipitation was two times lower than the long-term average and mean daily temperatures were close to long-term values.

$\beta$-glucan content was determined enzymatically following procedures of commercial kits obtained from Megazyme (Megazyme International Ireland Ltd.) according to the method developed by McCleary and Glennie-Holmes (1985). Analyses were made at the State Stende Cereal Breeding Institute.

The obtained results were statistically processed by the MS Excel software package using methods of descriptive statistics. Analysis of variance (ANOVA) was used for statistical data analysis. The significance of the effects of factors was determined at $p=0.05$.

\section{RESULTS}

Meteorological conditions including precipitation can limit nitrogen uptake effectivity in plants. The HTC I value for the period between sowing and nitrogen application was higher in 2013 and the value of 2.1 indicated that the soil was wet before nitrogen application (Table 2). HTC I in

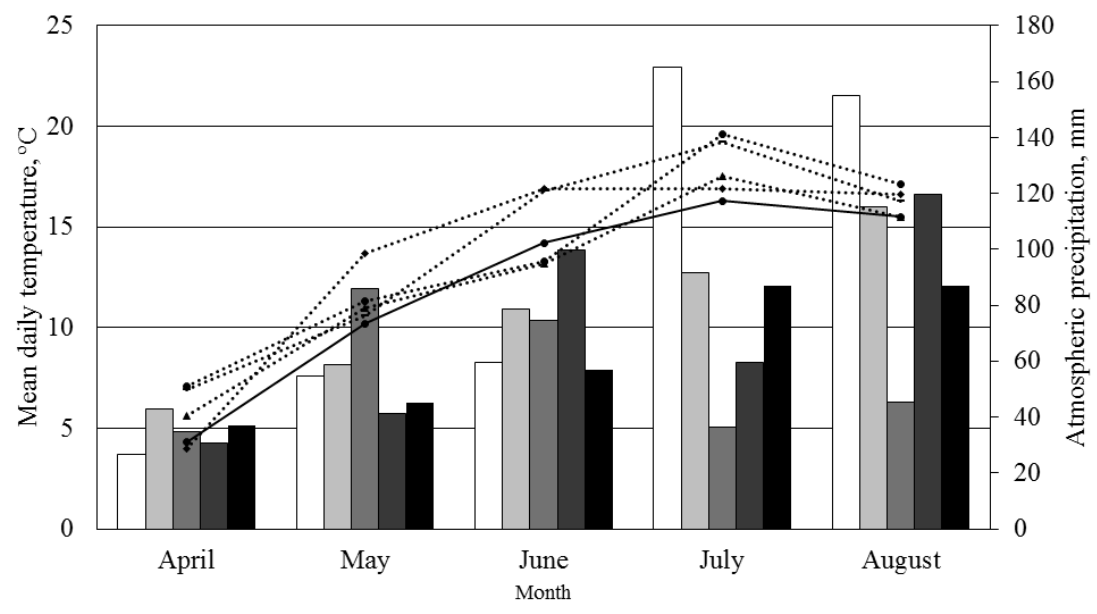

Fig. 1. Mean daily temperature and atmospheric precipitation dynamics (2011-2014, State Stende Cereal Breeding Institute):

$\square 2011,=2012, \square 2013, \square 2014, \square$ LTA Long-term mean temperature

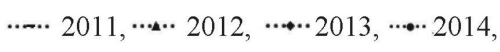

$\rightarrow$ Long-term mean precipitation. 
Table 2

METEOROLOGICAL CONDITIONS AFTER SOWING AND NITROGEN APPLICATION DATES (2011-2014, STATE STENDE CEREAL BREEDING INSTITUTE)

\begin{tabular}{l|c|c|c|c}
\hline \multirow{2}{*}{ Indices } & \multicolumn{4}{c}{ Year } \\
\cline { 2 - 5 } & 2011 & 2012 & 2013 & 2014 \\
\hline Mean daily temperature $\mathrm{I}^{1},{ }^{\circ} \mathrm{C}$ & 9.50 & 10.94 & 13.86 & 8.45 \\
Sum of precipitation I, mm & 40.90 & 31.20 & 49.90 & 33.60 \\
HTC I & 1.10 & 1.10 & 2.10 & 1.00 \\
Nitrogen application date & May 18 & May 23 & May 22 & May 15 \\
Mean daily temperature II, ${ }^{\circ} \mathrm{C}$ & 13.10 & 12.60 & 14.40 & 16.10 \\
Sum of precipitation II, mm & 6.70 & 12.30 & 35.10 & 33.90 \\
HTC II & 0.70 & 0.00 & 3.49 & 3.58 \\
Mean daily temperature III, ${ }^{\circ} \mathrm{C}$ & 12.90 & 8.90 & 18.10 & 14.40 \\
Sum of precipitation III, mm & 5.10 & 20.90 & 16.60 & 35.10 \\
HTC III & 0.60 & 0.00 & 1.31 & 3.49 \\
HTC May & 1.05 & 0.85 & 2.23 & 0.61 \\
HTC June & 1.18 & 2.27 & 1.47 & 2.19 \\
HTC July & 2.78 & 2.85 & 0.69 & 0.97 \\
HTC August & 2.41 & 5.62 & 0.25 & 1.52
\end{tabular}

${ }^{1}$ I - period from sowing to nitrogen application, II - first week after nitrogen application, III - second week after nitrogen application

other years was in the range of 1.0-1.3 (insufficiently wet). The HTC II value in the first two seasons indicated extremely dry ( 0.7 and 0$)$ conditions and in the others was extremely wet (3.49 and 3.58). In 2013, HTC values in July and August, when quality parameters are forming in grain, were extremely low (July 0.69 and August 0.25 ) compared with other years.

Content of $\beta$-glucan in naked oat genotypes was significantly $(p<0.05)$ higher, compared with that in the husked oat genotype. Figure 2 shows $\beta$-glucan content in relation to nitrogen application rates for husked oat genotype 'Lizete'. $\beta$-glucan content was higher with higher nitrogen application rate in 2011, 2012 and 2013, while the opposite occurred in 2014. There were significant differences $(p<$ $0.05)$ in $\beta$-glucan content between nitrogen application treatments and between trial years.

Figure 3 shows $\beta$-glucan content in relation to nitrogen application rate for the naked oat breeding lines 'S-156' and '33793'. $\beta$-glucan content did not differ significantly $(p>$ 0.05 ) between breeding lines nor between nitrogen application treatments, but the differences among years were significant $(p<0.05)$. Significantly higher $(p<0.05) \beta$-glucan content was observed in 2011, compared with that in 2012 and 2013 for both breeding lines. Differences in $\beta$-glucan content between 2011 and 2014 were significant $(p<0.05)$ only for breeding line 'S-156'.

\section{DISCUSSION}

Oat is studied mostly as a raw material for the human diet. The typical parameters described (yield from hectare, volume weight, husk and crude protein content) do not characterise oat nutritive and dietary value. Oat differ from other cereals by its unique biochemical structure and high

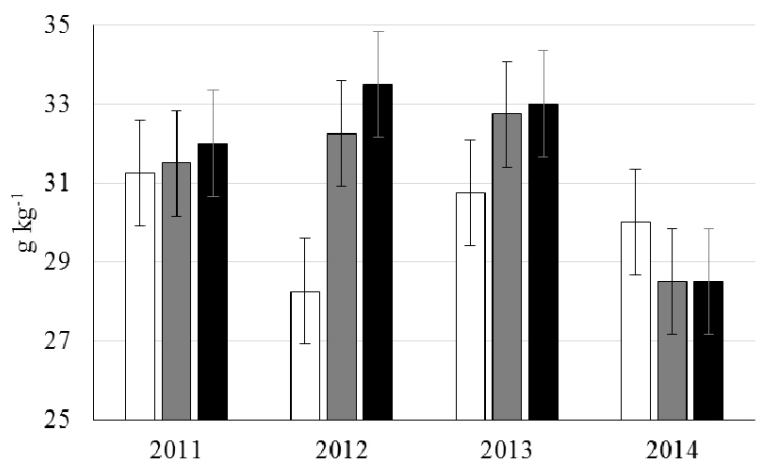

Fig. 2. $\beta$-glucan content of husked oat variety 'Lizete' at different nitrogen application rates $\left(\mathrm{mg} \cdot \mathrm{kg}^{-1}\right.$ dry matter, 2011-2014, State Stende Cereal Breeding Institute):

$\square \mathrm{N} 80, \square \mathrm{N} 120, \square \mathrm{N} 160$; error bars indicate the last significant difference (LSD).

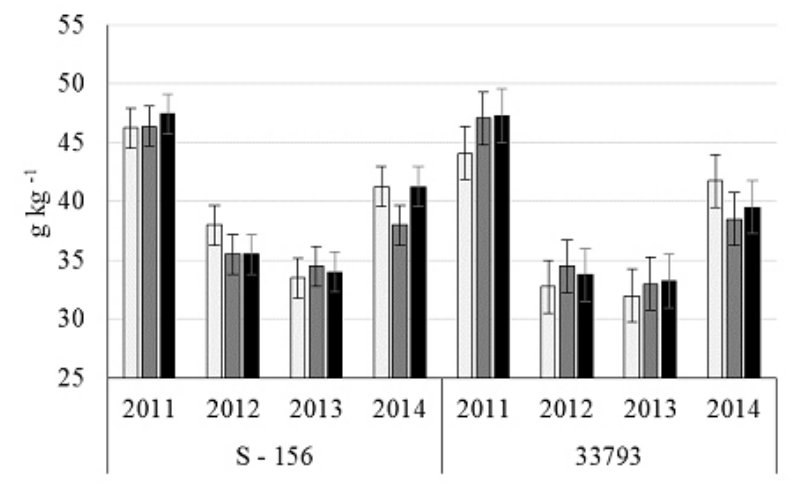

Fig. 3. $\beta$-glucan content of naked oat breeding lines at different nitrogen application rates $\left(\mathrm{mg} \cdot \mathrm{kg}^{-1}\right.$ dry matter, 2011-2014, State Stende Cereal Breeding Institute):

$\square \mathrm{N} 80, \square \mathrm{N} 120, \square \mathrm{N} 160 ;$ error bars indicate the last significant difference (LSD).

amounts of valuable nutrients such as soluble fibres, proteins, unsaturated fatty acids, vitamins, minerals and phytochemicals (Sadiq Butt et al., 2008). $\beta$-glucan content in oat grains was reported to range from 17.3 to $57.0 \mathrm{~g} \cdot \mathrm{kg}^{-1}$ (Lee et al., 1997; Redaelli et al., 2003; Havrlentova and Kraic, 2006), and there are significant differences between husked and naked oat genotypes in $\beta$-glucan content (Biel et al., 2014). Recent studies have shown that naked oat genotypes have higher concentrations of $\beta$-glucans (39.2 to $48.9{\mathrm{~g} \cdot \mathrm{kg}^{-1}}^{-1}$ ) compared with those in husked oats (27.5 to $34.7 \mathrm{~g} \cdot \mathrm{kg}^{-1}$ ) (Biel et al., 2014). Our obtained values of $\beta$-glucan content were similar to the results found in literature. In our study, $\beta$-glucan content ranged from 28.3 to $33.5 \mathrm{~g} \cdot \mathrm{kg}^{-1}$ for husked and from 32.0 to $47.4 \mathrm{~g} \cdot \mathrm{kg}^{-1}$ for naked oat genotypes, depending on growing season and nitrogen application rate. The difference between husked and naked oat genotypes can be explained by morphology; husked oat include also husk which lacks $\beta$-glucan, while naked oat kernels were free from husk. This is confirmed by analysis of $\beta$-glucan content in oats with husk and mechanically removed husk of the same genotypes. Biel et al.

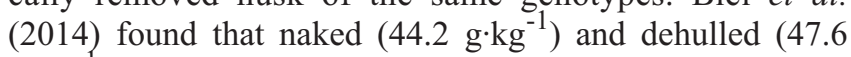
$\left.\mathrm{g} \cdot \mathrm{kg}^{-1}\right)$ oats contain significantly more $\beta$-glucan than husked oats $\left(31.2 \mathrm{~g} \cdot \mathrm{kg}^{-1}\right)$. 
Environmental conditions can affect $\beta$-glucan content in oat grain. High precipitation during ripening can reduce $\beta$-glucan concentration in oat grains (Brunner and Freed, 1994). Doehlert et al. (2001) found a positive correlation between precipitation sum in the last two months before harvest and $\beta$-glucan concentration in oat grains. Temperatures and precipitation sum are the main climatic factors influencing oat growth and development. Havrlentova et al. (2013) found that the growing year did not significantly affect $\beta$-glucan concentration in grains. Our research showed significant $(p<0.05)$ effect of growing season on $\beta$-glucan content of husked and naked oats. $\beta$-glucan content for naked oat was significantly $(p<0.05)$ higher in 2011 , when HTC values in May and June showed insufficiently wet conditions, and in July and August - very wet conditions. The lowest $\beta$-glucan content for naked oat was observed in 2013 when the HTC value at the beginning of growing season was higher and at the end of growing period was lower (very dry) compared with those in other years. Contrasting results were described by Saastamoinen et al. (2004), where $\beta$-glucan content was lower during a cold and rainy year compared to that in a dry and hot year. Interaction of HTC values in the three periods with nitrogen application effectivity and $\beta$-glucan content in oat grains was not observed. Significant $(p<0.05)$ differences in $\beta$-glucan content were observed between 2011 and 2012, but HTC values of these years were quite similar. Differences among nitrogen application treatments in the amount of $\beta$-glucan were significant $(p<0.05)$ only for husked oat genotype. Similarly, Havrlentova et al. (2013) observed that $\beta$-glucan content of husked oat was significantly affected by nitrogen fertilisation, while content of naked oat was affected only by genotype. Fan et al. (2009) did not observe significant differences in content of $\beta$-glucan among nitrogen treatments.

We observed significant differences in $\beta$-glucan content between husked and naked oat genotypes, and the effects of metrological conditions and nitrogen application on $\beta$-glucan content in oat grains. But information found in the literature is contradictory. We need to continue our research to gain clearer understanding of $\beta$-glucan accumulation in oat grains using more husked and naked oat varieties. This could help to develop breeding criteria for new varieties, which would aid development of healthy food.

\section{ACKNOWLEDGEMENTS}

This work was supported by the European Social Fund co-financed Project "Establishment of new scientific group for multi-branch research for assessment of local cereal material on characteristics determining the dietary potential and their use possibilities in the prevention of chronic bowel diseases" No. 1DP/1.1.1.2.0/13/APIA/VIAA/032.

\section{REFERENCES}

Anonymous (2014). FAO Statistical Yearbook 2014: Europe and Central Asia Food and Agriculture. Food and Agriculture Organization of the United Nations Regional Office for Europe and Central Asia. Budapest. 130 pp.

Biel, W., Bobko, K., Maciorowski, R. (2009). Chemical composition and nutritive value of husked and naked oats grain. J. Cereal Sci., 49, 413-418.

Biel, W., Jacyno, E., Kawecka, M. (2014). Chemical composition of hulled, dehulled and naked oat grains. South African J. Animal Sci., 44 (2), 189-197.

Brunner, B. R., Freed, R. D. (1994). Oat grain $\beta$-glucan content as affected by nitrogen level, location and year. Crop Sci., 34, 473-476.

Doehlert, D. C., McMullen, M. S., Hammond, J. J. (2001). Genotypic and environmental effects on grain yield and quality of oat grown in North Dakota. Crop Sci., 41, 1066-1072.

Fan, M., Zhang, Z., Wang, F., Li, Z., Hu, Y. (2009). Effect of nitrogen forms and levels on $\beta$-glucan accumulation in grains of oat (Avena sativa L.) plants. J. Plant Nutr. Soil Sci., 172, 861-866.

Havrlentova, M., Kraic, J. (2006). Content of $\beta$-D-glucan in cereal grains. J. Food Nutr. Res., 45 (3), 97-103.

Havrlentova, M., Hlinkova, A., Žofajova, A., Kovačik, P., Dvončova, D., Deakova, L. (2013). Effect of fertilization on $\beta$-glucan content in oat grain (Avena sativa L.). Agriculture (Polnohospodarstvo), 59 (3), 111-119.

Lee, C. J., Horsley, R. D., Manthey, F. A., Schwarz, P. B. (1997). Comparisons of $\beta$-glucan content of barley and oat. Cereal Chem., 74 (5), 571-575.

McCleary, B.V., Glennie-Holmes, M. (1985). Enzymic quantification of (1-3), (1-4)- $\beta$-D-glucan in barley and malt. J. Inst. Brewing, 91, pp. 285-295.

Redaelli, R., Sgrulletta, D., De Stefanis, E. (2003). Genetic variability for chemical components in sixty European oat (Avena sativa L.) cultivars. Cereal Res. Comm., 31 (1-2), 185-192.

Saastamoinen, M., Hietaniemi, V., Pihlava, J. M., Eurola, M., Kontturi, M., Tuuri, H., Niskanen, M., Kangas, A. (2004). Beta-glucan contents of groats of different oat cultivars in official variey, in organic cultivation, and nitrogen fertilization trials in Finland. Agr. Food Sci., 13 (1-2), 68-79.

Sadiq Butt, M., Tahir-Nadeem, M., Khan, M. K. I., Shabir, R. (2008). Oat: Unique among the cereals. Eur. J. Nutr., 47, 68-79.

Taparauskiene L., Laukševičiūte V., Maziliauskas A. (2013). Comparison of standardized precipitation and Selyaninov hydrothermal drought indices. Rural Development 2013, 486-489.

Tiwari, U., Cummins, E. (2009). Simulation of the factors affecting $\beta$-glucan levels during the cultivation of oats. J. Cereal Sci., 50, 175-183.

Wood, P. J. (2007). Cereal $\beta$-glucans in diet and health. J. Cereal Sci., 46, 230-238.

Received 4 June 2015

\section{SLĀPEKḶA MĒSLOJUMA NORMU UN METEOROLOĢISKO APSTĀKḶU IETEKME UZ $\beta$-GLIKĀNU SATURU KAILGRAUDU UN PLĒKŠN̦AINO AUZU GRAUDOS}

Pētījuma mērkis bija noskaidrot izmantotā slāpekḷa virsmēslojuma normu ietekmi uz $\beta$-glikānu saturu auzu graudos. Pētījums veikts Valsts Stendes graudaugu selekcijas institūtā no 2011. līdz 2014. gadam. Tajā iekḷauti divi kailgraudu auzu genotipi (selekcijas līnijas 'S-156' un '33793') un viens plēkšnnaino auzu genotips (škirne 'Lizete'), trīs slāpekḷa virsmēslojuma fonos (80, 120 un 160 kg ha ${ }^{-1}$ tīrvielā). Kailgraudu auzās $\beta$-glikānu saturs bija būtiski $(p<0.05)$ augstāks, salīdzinot ar plēkšņaino auzu genotipu. Būtiskas atšķirības $\beta$-glikānu saturos starp abām kailgraudu auzu līnijām netika konstatētas. Būtiskas atšķirības $\beta$-glikānu saturā starp dažādām slāpekḷa mēslojuma normām tika novērotas tikai plēkšņaino auzu genotipam 'Lizete'. Izmēgeinājuma gada ietekme uz $\beta$-glikānu saturu bija būtiska $(p<0.05)$ abiem auzu genotipiem (plēkšņainajam un kailgraudu). $\beta$-glikānu saturs kailgraudu genotipa līnijām 'S-156' un '33793' būtiski augstāks bija 2011. gadā, salīdzinot ar 2012. un 2013. gadu, pietiekamu nokrišṇu dēl graudu veidošanās un piebriešanas periodā. 